\title{
Nobel Prize Commemoration in Riga: Media Echo and Objects
}

\section{Abstract}

This paper is an attempt to investigate the discourses around the Nobel Prize, and it aims at deciphering the commemoration of the award in Riga. The public image of the Nobel Prize in Riga has previously been commented on in a few papers, but has never been studied at length. The first part of the current study contextualises several Nobel links from the city, universities and state printed media, as well as more hidden tracks from the Nobel Prize nominations' archive. The second part highlights Ilya Mechnikov (Elie Metchnikoff's, Nobel laureate in physiology or medicine in 1908) collection in Pauls Stradins Museum of the History of Medicine, including a detailed description of his Nobel medal and his ambivalent feelings about this award.

Keywords: Nobel Prize, Latvian press, Riga, Baltic States, Ilya Mechnikov (Elie Metchnikoff), Paul Ehrlich, Wilhelm Ostwald, Paul Valden, Ernst von Bergmann, Harald zur Hausen.

Several compendia on the history of medicine use the Nobel Prize in physiology or medicine as a lens for reviewing scientific trends in the history of medicine in the last century. The medical historian Erwin Ackerknecht, for instance, argued that the tendencies of the $20^{\text {th }}$ century cutting-edge medicine are illustrated by the names of those who received the Nobel Prize. ${ }^{1}$

1 Erwin H. Ackerknecht, A short history of medicine (New York: Johns Hopkins University Press, 1968). 
Also, more recent textbooks, such as Ortrun Riha's Grundwissen Geschichte, Theorie und Ethik der Medizin², Jacalyn Duffin's History of Medicine: A Scandalously Short Introduction ${ }^{3}$, Tatiana Sorokina's History of Medicine 4 have (at least in some editions) enclosed lists of Nobel laureates to highlight prominent work throughout the $20^{\text {th }}$ century. Some key discoveries and fields in basic and clinical research are represented in the work of the laureates and their research teams, starting with the first prizes at the turn of the $20^{\text {th }}$ century honouring progress in research regarding, for example, diphtheria (Emil von Behring, 1901), malaria (Ronald Ross, 1902), and tuberculosis (Robert Koch, 1905). ${ }^{5}$

However, not only medical historians alone celebrate the laureates and their achievements. Over the years, the Nobel Prize has evolved to become a well-known symbol of scientific excellence to a wide general public. ${ }^{6}$ Each year in October (prize announcement) and in December (prize ceremony), world media covers different approaches of the awarded Nobel Prizes in its five categories: physics, chemistry, physiology or medicine, literature, and peace. In fact, it is still an exciting open question why this award from a small country in northern Europe has reached such outstanding reputation. It can be learnt from the contributions on Nobel Prize history that there are several factors, such as international ambition and large prize sum (initially, around one million US-Dollar). ${ }^{7}$ Furthermore, the direct connection to the worldrenowned inventor of dynamite Alfred Nobel as well as its long tradition (the first Nobel Prize was awarded in 1901) play roles for its unique standing. ${ }^{8}$

2 Ortrun Riha, Grundwissen Geschichte, Theorie, Ethik der Medizin. Querschnittsbereich 2 (Bern: Verlag Hans Huber, 2008).

3 Jacalyn Duffin, History of Medicine: A Scandalously Short Introduction (Toronto: University of Toronto Press, 1999).

4 Tatiana Sorokina, Istoriia meditsiny (v 2-kh tomakh) (Moskva: Akademiia, 2018).

5 Nils Hansson, Thorsten Halling, eds, It's Dynamite - Der Nobelpreis im Wandel der Zeit (Göttingen: Cuvillier Verlag, 2017); Thorsten Halling, Heiner Fangerau, Nils Hansson, eds., Berichte zur Wissenschaftsgeschichte, Special Issue Der Nobelpreis. Konstruktion von Exzellenz zu Beginn des 20. Jahrhunderts 41, no. 1 (2018): 1-103; Nils Hansson, Thorsten Halling, Heines Fargeran, Attributing Excellence in Medicine: The History of the Nobel Prize (Brill, 2009) (in Press).

6 Sven Widmalm, ed., Public Understanding of Science, Special Issue "The Nobel Prizes and the Public Image of Science," 27, no. 4 (2018): 390-488.

7 Robert Marc Friedman, The Politics of Excellence: Behind the Nobel Prize in Science (New York: Times Books, Henry Holt and Company, 2001).

8 Tore Frängsmyr, Alfred Nobel (Stockholm: Swedish Institute, 2004); Ulf Larsson, Alfred Nobel: Networks of Innovation, Archives of the Nobel Museum 
Still, some other prestigious prizes that are maintained as awards have a longer history (like the Copley medal, awarded since 1731 by the Royal Society in London), ${ }^{9}$ and others have a larger prize sum (e. g. the Breakthrough Prize). However, no other award or medal can compete with the reputation of the Nobel Prize within global scientific communities or for laymen. Given its legacy, it has also been used as a marketing tool. Ivy League-institutions like Harvard University and Yale University, and scientific societies like the German national Academy Leopoldina proudly include lists of Nobel laureates somehow linked to them at their homepages. ${ }^{10}$ This Nobel "claim-to-fame" can also be seen in other countries and cities. Recent symposia and exhibitions in Göttingen, ${ }^{11}$ Berlin, ${ }^{12}$ and Zürich (with the exhibition "Einstein \& Co. Zürich und der Nobelpreis") have emphasised their Nobel connections with a particular focus on "their" laureates. The interest persists: alike symposia took place at Harvard Medical School in October 2018 entitled "The History, Uses, and Future of the Nobel Prize" and in December 2018 at the University of Berne ("Braucht die Forschung Preise? Nobelpreise und Auszeichnungen in der Schweiz"). This paper is an attempt to provide some traces of manifestations, studying primarily media discourses on the award and "heritage" in Riga with "Nobel connections". Perhaps the most obvious link is Wilhelm Ostwald (1853-1932) who was born in Riga, graduated Tartu University (Dorpat University

(Stockholm: Nobel Museum, 2008); Ragnar Sohlman, The Legacy of Alfred Nobel (London: The Bodley Head, 1983); Henrik Schück et al., Nobel. The Man and His Prizes (Stockholm: Solhmans Förlag, 1950); Svante Lindqvist, A Tribute to the Memory of Alfred Nobel: Inventor, Entrepreneur and Industrialist (1833-1896) (Stockholm: Royal Swedish Academy of Engineering Sciences, 2001), IVA Note 335.

${ }^{9}$ R.M.MacLeod, Of medals and men: a reward system in Victorian science, 1826-1914, Notes and Records of the Royal Society of London, 26, no. 1 (1971): 81-105.

${ }^{10}$ Nils Hansson, "Anmerkungen zur wissenschaftshistorischen Nobelpreisforschung," Berichte zur Wissenschaftsgeschichte, 41, no. 1 (2018): 7-18; Thorsten Halling, Nils Hansson and Heiner Fangerau, "Prisvärdig" Forschung? Wilhelm Roux und sein Programm der Entwicklungsmechanik," Berichte zur Wissenschaftsgeschichte, 41, no. 1 (2018): 73-97.

11 Elmar Mittler und Fritz Paul, eds., Das Göttinger Nobelpreiswunder - 100 Jahre Nobelpreis: Vortragsband, (Göttingen: Niedersächsische Staats- und Universitätsbibliothek Göttingen, 2004).

12 Nils Hansson, Thorsten Halling, eds., It's Dynamite - Der Nobelpreis im Wandel der Zeit. 
(1802-1917) and afterwards was a professor at Riga Polytechnicum (since 1896 Riga Polytechnic Institute, Faculty of Chemistry). He was awarded the Nobel Prize in chemistry in 1909 "in recognition of his work on catalysis and for his investigations into the fundamental principles governing chemical equilibria and rates of reaction". On the webpage of Riga Technical University, it is thus stated: "Wilhelm Ostwald - the only Nobel Prize Laureate from the Baltic States". ${ }^{13}$ Owing to this, on the statistics sites of the Nobel Scientific Prizes, Latvia is also mentioned among the top 50 countries in relation to prize winners. ${ }^{14}$

Two of Ostwald's students also had "Nobel connections". In 1886, Ostwald welcomed his first foreign student to Riga - a young Swedish scientist, the future Nobel Prize laureate Svante Arrhenius, who spent half a year working in Riga. The other student from Riga, a later well-known chemist Paul Valden, was, according to the Nobel Prize nomination database, nominated for the Nobel Prize nine times in 40 years. ${ }^{15}$ He never received one, though. Valden was also the first to nominate Ostwald for the Nobel Prize in chemistry in 1904.

The citizens of Riga are still proud of Wilhelm Ostwald and memorialise him in different ways. In 2001, the year of the $800^{\text {th }}$ anniversary of Riga, a monument with one of the most peculiar compositions that decorates the public space of the city was opened next to the fence of the Wöhrmann garden at Krišjānis Barons Street 8, near the house, where Ostwald lived when he was a chemistry professor in Riga. ${ }^{16}$ It is a bronze cast tracery by sculptor A. Vārpa containing a complex iconography about W. Ostwald. The monument opening ceremony on August 14, 2001 was attended by the President of Latvia then Vaira Vīkse-Freiberga and W. Ostwald's granddaughter Gretel Brauer. ${ }^{17}$

13 “History," Riga Technical University, accessed on June 27, 2018, https://www.rtu.lv/ en/university/history.

14 “Nobel Prize Winners By Country," accessed on November 5, 2018, https://www. worldatlas.com/articles/top-30-countries-with-nobel-prize-winners.html

15 “The Nobel Prize," accessed on June 27, 2018, https://www.nobelprize.org/nomination/archive/.

16 Jānis Stradiṇš, "Lai pazītu un godinātu savējos, rīdziniekus [To recognise and commemorate the kin, citizens of Riga]," Latvijas Véstnesis, August 5, 2001, 5.

17 Ojārs Spārītis, Riga's Monuments and Decorative Sculptures (Rīga: Nacionālais apgāds, 2007), 138. 


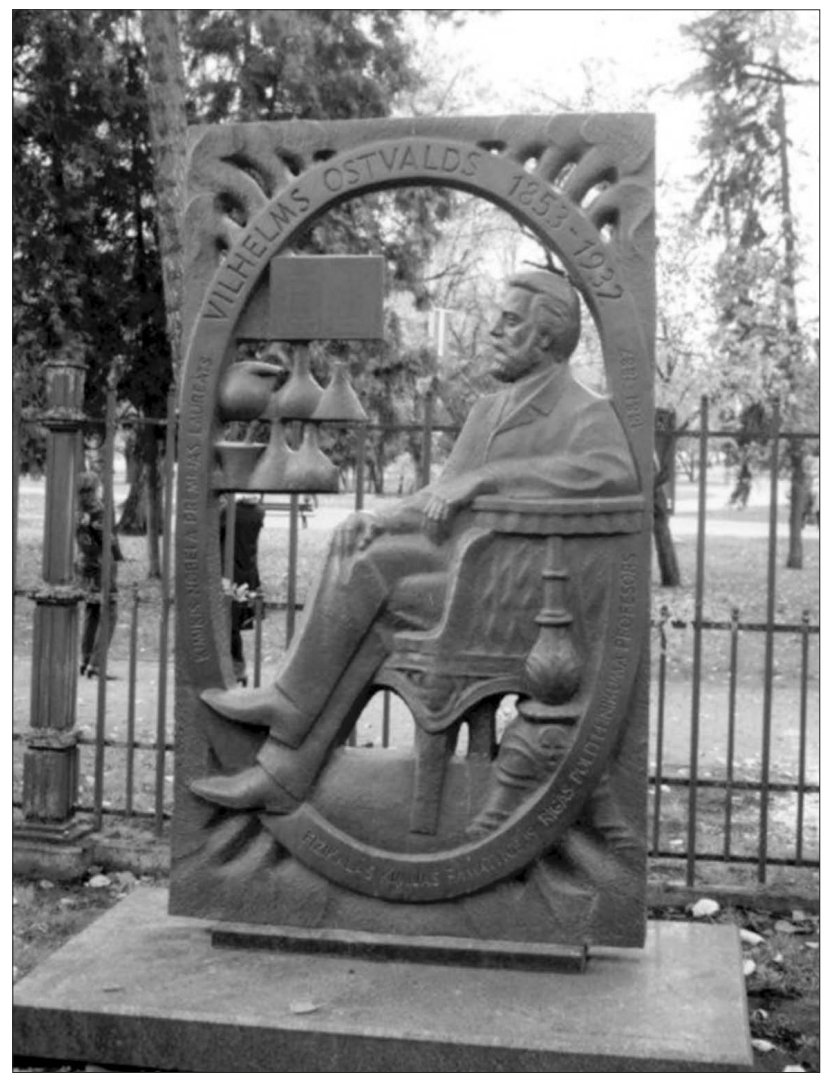

Monument dedicated to Wilhelm Ostwald in Riga (Sculptor: Andris Vārpa. 2001. Photographer: Artis Ērglis)

Ostwald was the first one to become an Honorary Member of Riga Polytechnical Institute. His name is present also in other places. There is, for instance, a secondary school named after him in Riga. The rumours spread that an urn with W. Ostwald's ashes is immured in a cliff on his estate "Energie" in Grossbothen near Leipzig that was named Wilhelm Ostwald Park in 2009. Whereas in Riga, in the closed Great Cemetery, a memorial plaque next to his parent and brother's graves was inaugurated in 2008. ${ }^{18}$

18 Jānis Stradiņš, Baltijas zinātņu vēstures konferences pusgadsimta gaitā: no Hruščova līdz Ilvesam (1958-2008) [In the course of the half-century of the Baltic Sciences History Conference: from Khrushchev to Ilves (1958-2008)], Acta medico-historica Rigensia, 9 (2010): 288. 


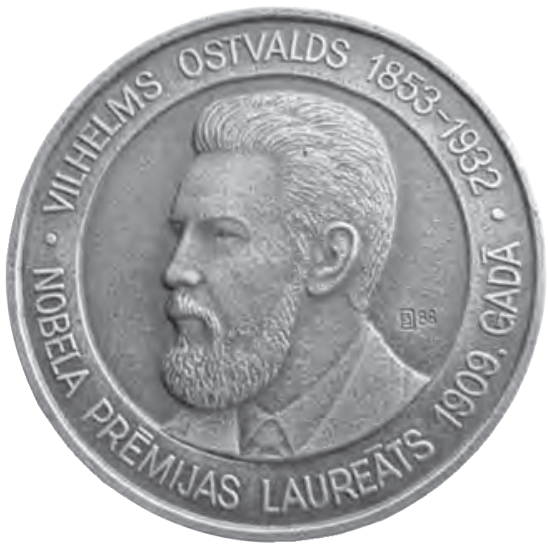

Medal dedicated to Wilhelm Ostwald. Avers

(Artist: Jānis Strupulis. 1988. Photographer: unknown.

From J. Strupulis private collection)

That is why there are fake news published in modern press about Ostwald's place of burial in Riga - either deliberately or due to ignorance. ${ }^{19}$

About a century later, two more Nobel Prize laureates related to Latvia appear in the statistics. ${ }^{20}$ The 2002 Nobel Prize in physiology or medicine was shared among three scientists "for their discoveries concerning genetic regulation of organ development and programmed cell death". Sydney Brenner, one of the laureates, has family roots in Latvia (his mother emigrated from Latvia in 1922). ${ }^{21}$

Another case is the Nobel Prize in literature in 1991, awarded to Nadine Gordimer "who through her magnificent epic writing has - in the words of Alfred Nobel - been of very great benefit to humanity". Her parents were both Jewish immigrants to South Africa; her mother from London and her father from Latvia. ${ }^{22}$

19 "Izcili rīdzinieki un viņu piemiņas vietas [Excellent Rigans and their memorial sites]," Rīgas Dome, accessed on July 24, 2018, http://www.delfi.lv/ turismagids/rigas-marsruti/lielie-kapi-romantiskais-parks-kur-atdusas-rigas-celajiun-veidotaji.d?id=50029561.

20 "Jau trīs Nobela laureātu dzimtas saistītas ar Latviju [Three of the Nobel laureates have already been associated with Latvia]," Latvija Amerikä, October 19, 2002, 19.

${ }^{21}$ Eli Rabinowitz, "Sydney Brenner," last modified in October, 2014, https://kehilalinks. jewishgen.org/germiston/Sydney_Brenner.html.

22 Dennis Walder, "Nadine Gordimer obituary," The Guardian, July 14, 2014. 


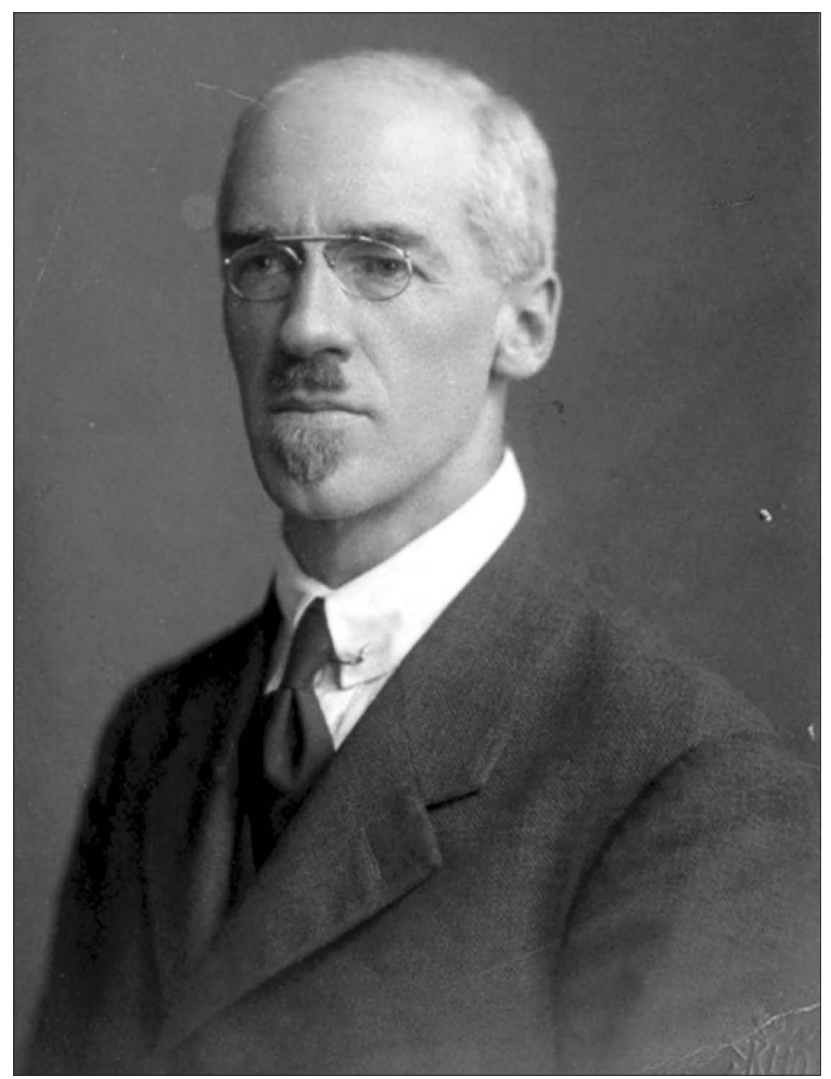

Professor Ernst Fehrmann (1872-1947). Riga, The 1920s (Photographer: photo studio of Vilis Rīdzenieks. MVM F 27840)

In the previously mentioned Nobel Prize nomination databank, there are more hints at physicians who made suggestions and physicians who were suggested for the prize but have never been granted. It is the case of the professor of hygiene from the University of Latvia Ernst Fehrmann (1872-1947) who nominated the two Harvard professors George Minot and William Murphy for the physiology or medicine-prize in 1929 because of their research on pernicious anaemia (they received it jointly with George Whipple five years later).

We can also name the surgeon Ernst von Bergmann, born in Riga in 1836. He was nominated for the Nobel Prize in physiology or medicine by the German surgeon Vincenz Czerny in 1903. 


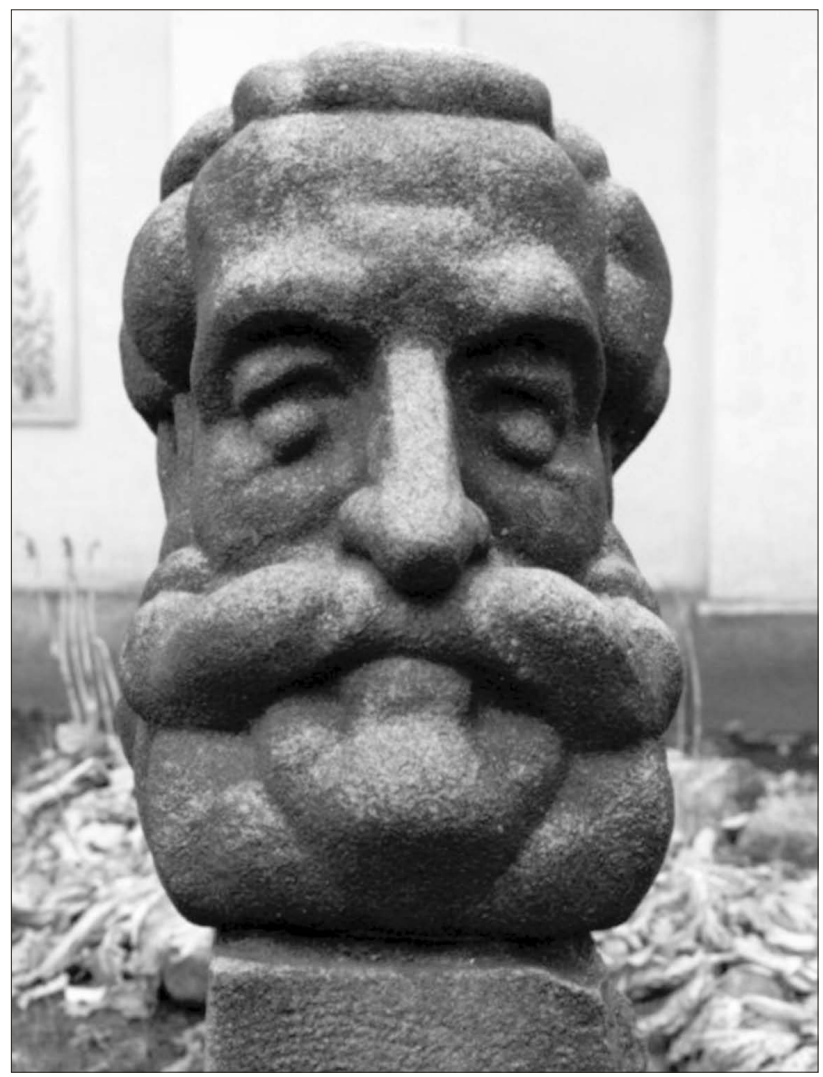

Sculpture - Ernst von Bergmann

(Sculptor: Ojārs Breǵis. 1971. Riga.

Photographer: Jānis Pavlovskis. MVM_1070_LA_7097)

In his nomination letter, Czerny first proposed Lord Joseph Lister for antisepsis research, and then von Bergmann because of his antisepsis work and other publications. ${ }^{23}$ However, neither Bergmann nor Lister ended up at the "shortlist" of the Nobel Committee. Czerny also mentioned Ivan Pavlov as the third candidate, who received the award one year later (1904). In Germany and Latvia, Bergmann is still commemorated as a pioneer surgeon.

23 Nils Hansson, Annette Tuffs, "Nominee and nominator, but never Nobel Laureate: Vincenz Czerny and the Nobel Prize," Langenbeck's Archives of Surgery, 401, no. 8 (2016): 1093-1096, doi:10.1007/s00423-016-1511-3. 


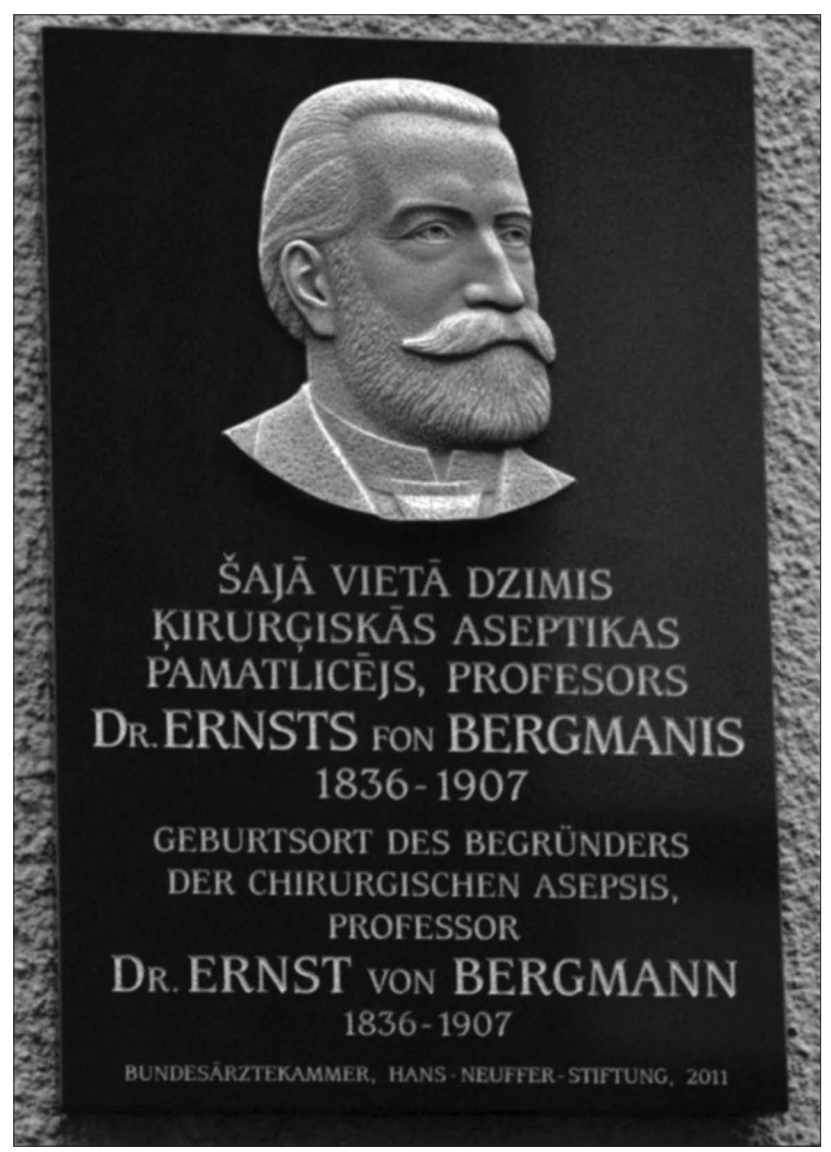

Memorial plate dedicated to Ernst von Bergmann

(Sculptor: Jānis Strupulis. 2011. Riga.

Photographer: Didzis Kadaks)

The German Society of Surgery awards an "Ernst-von-BergmannGedenkmünze in Gold", ${ }^{24}$ and in Riga Bergmann remains well-known due to his stone sculpture in the yard of Pauls Stradins museum of the History of Medicine, memorial plate on the building in Peldu street 11 in the Old Town of Riga and the street has his name in a residential part of Riga, "Mežaparks" district.

24 R. Czymek and W. Düsel, "On the centennial of Ernst von Bergmann's death," Der Chirurg 78, no. 3 (March 2007): 265-272. 

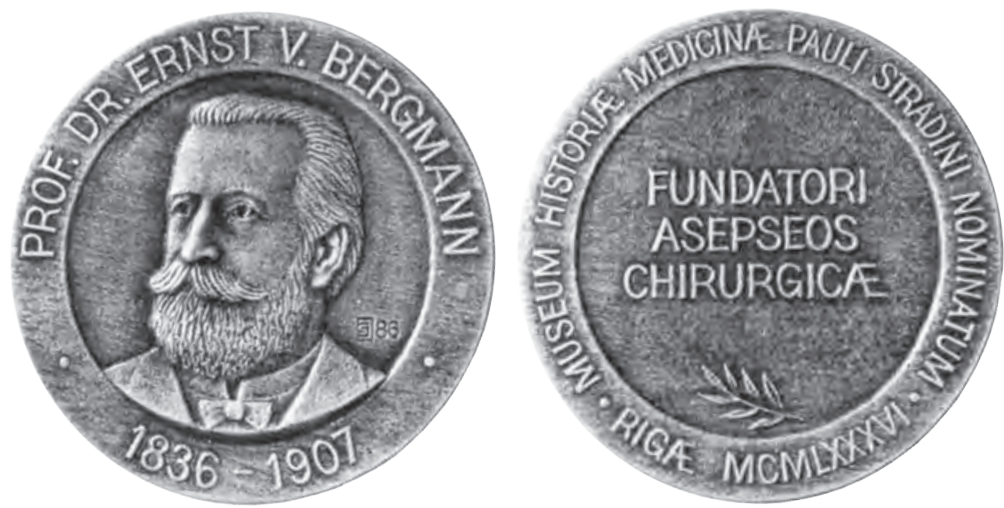

Medal dedicated to 150-ty anniversary of Ernst von Bergmann. Avers and revers (Artist: Jānis Strupulis. 1986. Photographer: Pauls Cīrulis. MVMp 13798 Fnp 7006; MVMp 13797 Fnp 7005)

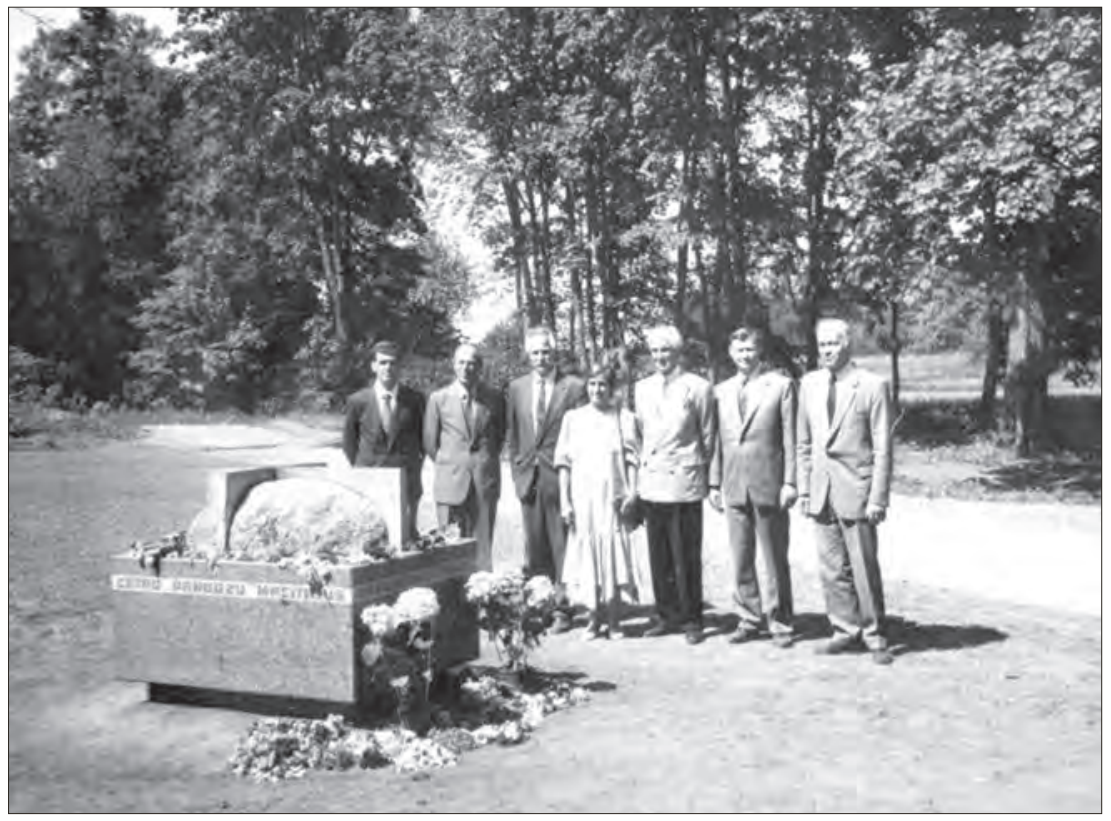

Opening ceremony of the memorial stone dedicated to Ernst von Bergman family. June 1992, Rūjiena (Latvia). Ernst von Bergman's grandchildren:

the $3^{\text {rd }}$ from the left: Klaus von Bergmann (b. 1940), the $4^{\text {th }}$ from the left: Helga Reeck (b. 1936). (MVMp 16467/1 Ffp 3488/1) 


\section{Nobel Prize links: Estonia and Lithuania}

Nobel connections can be traced also in Estonia and Lithuania. In 1977, one half of the Nobel Prize in physiology or medicine was awarded jointly to the American-Polish endocrinologist Andrew Schally who was born in Vilnius and his colleague Roger Guillemin "for their discoveries concerning the peptide hormone production of the brain". ${ }^{25}$

Lithuanian-born Polish writer Czeslaw Milosz received the Nobel Prize in literature in 1980 as an author "who with uncompromising clear-sightedness voices man's exposed condition in a world of severe conflicts". ${ }^{26}$ Several memorial objects in Lithuania are dedicated to him Czeslaw Milosz Cultural Centre in his native Šeteniai, stairs named after him in the Old Town Vilnius at the intersection of Bokštas (Tower) and Ona Šmaite (Lithuanian librarian at Vilnius University) streets with lines of his poetry painted on the stairs. There is also a marker on the wall of Literatu St. (along with other famous Lithuanian writers) and a memorial plaque in the Sarbievius Courtyard of Vilnius University (the Old Campus).

The Lithuanian-born British-South African chemist Aaron Klug was awarded the Nobel Prize in chemistry in 1982 "for his development of crystallographic electron microscopy and his structural elucidation of biologically important nucleic acid-protein complexes". ${ }^{27}$

In 1985, the Nobel Peace Prize was awarded to the physician organisation "International Physicians for the Prevention of Nuclear War", cofounded by Yevgeniy Chazov and a Lithuanian-born American physician Bernard Lown, who designed the modern-day monophasic defibrillator in 1959. His achievements have also been acknowledged by the modern-day Lithuania by awarding him with the Cross of Commander of the Order of the Grand Duke Gediminas.

The 2013 Nobel Prize laureate in economics Robert Shiller is of Lithuanian descent.

\footnotetext{
25 "The Nobel Prize in Physiology or Medicine 1977," The official web site of the Nobel Prize, accessed on June 24, 2018, https://www.nobelprize.org/nobel_prizes/medicine/ laureates/1977/.

26 “The Nobel Prize in Literature 1980," The official web site of the Nobel Prize, accessed on June 24, 2018, https://www.nobelprize.org/nobel_prizes/literature/laureates/1980/.

27 "The Nobel Prize in Chemistry 1982," The official web site of the Nobel Prize, accessed on June 24, 2018, https:/www.nobelprize.org/nobel_prizes/chemistry/laureates/1982/.
} 
As to Estonia, there are no Nobel Prize laureates. Mostly writers have been nominated: Marie Under (six times), as well as Jaan Kross and Jaan Kaplinski. There have been many Tartu University faculty members among the nominees for the Nobel Prize, e.g. the anatomy professor August Rauber, Director of the Tartu University Institute of Anatomy.

Tartu University is proud of the fact that the Nobel Prize laureate Wilhelm Ostwald enrolled at Imperial Tartu University (now Tartu University, Estonia) in 1872, where he studied chemistry under Carl Schmidt and received a candidate's degree (1875), a master's degree (1876), and a $\mathrm{PhD}$ (1878). ${ }^{28}$ It is commemorated in a marble plaque with bronze relief portrait of Ostwald on the wall of the main building of the University of Tartu, designed by the Estonian sculptor Mati Karmin. ${ }^{29}$

Latvia neighbour countries Estonia and Lithuania also have Nobel Prize history regarding nominations, nominees and winners. For all three countries, common is the fact that no one was a "pure" Nobel prize winner, e.g., born, studied and lived in one of the Baltic states.

\section{The Nobel Prize in the Latvian press}

The Latvian press has regularly highlighted various aspects of the Nobel Prize venture. The press articles of the $20^{\text {th }}$ and early $21^{\text {st }}$ century show that the articles have been published throughout the year with most of the publications from October to December. This is in line with the international trends. ${ }^{30}$ Before the end of the Second World War, there were articles of both national and local relevance published on the topic in Latvian, Russian and German in Riga newspapers.

The coverage of the Nobel Prize in the $20^{\text {th }}$ century Latvian press can be divided in four periods: 1) publications before the Second World War (by 1918 the territory of Latvia was a part of Russian Empire; afterwards Independent Latvia (1918-1940)); 2) Second World war; 3) between 1945 and 1991 (Soviet period); 4) after regaining the independence of Latvia in 1991 and onwards. During the first period, the financial worth and its

28 Joachim Schummer, "Wilhelm Ostwald," Encyclopaedia Britannica, accessed on March 29, 2018, https:/www.britannica.com/biography/Wilhelm-Ostwald.

29 “Reliefs," Mati Karmin portfolio, accessed on June 24, 2018, http://karmin.ee/reliefs.

30 Baram-Tsabari Ayelet and Segev Elad, "The half-life of a "teachable moment": The case of Nobel laureates," Public Understanding of Science, 24, no. 3 (2015): 326-337, https://doi.org/10.1177/0963662513491369. 
equivalent in the national currency (Russian Empire roubles, Latvian roubles or lats) was described in detail. During the third period the topic of the articles was strictly ideologised which is seen both in the Soviet Latvian newspapers and magazines in Latvian and Russian and Latvian exile publications in Sweden, the USA, Australia and elsewhere. The fourth period that started after the restoration of the independence of Latvia in 1991 is characterised by an informative and analytical style.

\section{$* * *$}

In 1896, "Baltijas Vēstnesis" and other newspapers published an erroneous telegraph message from San-Remo that Alfred Nobel had passed away on December 11, 1896 (November 29, according to the old style). His will was not mentioned in the message. ${ }^{31}$

On the first day of 1897, several years before awarding the first prizes, the newspaper "Tēvija" informed about the content of A. Nobel's will, noting that Nobel had donated practically all of his estate to the development of science, by creating five annual prizes. ${ }^{32}$

Later, the use of Nobel's legacy was clarified in detail in local Baltic German newspapers. ${ }^{33}$

After awarding the first prizes in 1901, the interest in the stories about Nobel's legacy grew. In 1902, the authors of the article mentioned the first-year laureates (it was E. Behring in medicine) and speculated about the potential laureates of the second prize. Robert Koch and Lord Joseph Lister were most commonly mentioned as the potential prize winners in physiology or medicine. ${ }^{34}$

A review of the first two decades of publications shows that recent laureates were not that central. Instead, the newspapers regularly repeated Alfred Nobel's biography and estimated the financial worth of the prize. An exception was the end of 1909 and the beginning of 1910, when over the period of four months more than 20 news releases and articles were published in Latvian and German newspapers in Riga on the Nobel Prize award of 1909 in chemistry to Ostwald. For example, "Mājas Viesis"

\footnotetext{
31 “Telegrammas [Telegrams]," Baltijas Vēstnesis, November 30, 1896, 3.

32 “Ārzemju ziṇas. Zviedrija [International news. Sweden]," Tēvija, January 1, 1897, 3.

33 “Eine Erbschaft von 60 Millionen," Düna Zeitung, Juli 8, 1898, 5.

34 “Nobela godalgas [Nobel prizes]," Dienas Lapa, November 2, 1902, 3.
} 
republished articles about Ostwald from "Frankfurter Zeitung" and "Berliner Tageblatt". 35

Awarding of the Nobel Prize to Ostwald determined a continued reference to him in relation to the Nobel Prize in local newspapers up to his death in $1932 .{ }^{36}$

During the interbellum, information about the Nobel Prize laureates became more popular. Sometimes, detailed laureates' biographies were published and their accomplishments were analysed. Individual publications regularly re-published official news (press release) of the Nobel Prize Committee. ${ }^{37}$

Almost every year Albert Nobel's biography was retold, sometimes using intriguing titles such as "Dynamite King Nobel's tragedy". ${ }^{38}$ The procedure for choosing laureates was retold - "Who awards the Nobel Prizes?". ${ }^{39}$ Also, critical articles about the prize awarding procedure were published - "The shadows of the culture". ${ }^{40}$ The author complained that the Nobel Prize had become "political" and decisions of the Nobel Committees were supportive to the already famous and well-established writers, instead of young talents.

Such and similar information was released by different publications during the fall-winter period every year: governmental, military-patriotic, economical, scientific, entertaining-illustrative, literary and other publications. The peak of the publications was in the 1930s. In 1933, as always, there were speculations about the potential nominees and laureates, but that year special attention was given to Alfred Nobel's personality due to his $100^{\text {th }}$ anniversary. ${ }^{41}$

35 Vilhelms Ostvalds, "Domas ziemas svētkos [Thoughts on Christmas]," Mãjas Viesis, 51 (December 23, 1909): 1001-1004.; Vilhelms Ostvalds, "Uz Stokholmu [To Stockholm]," Mājas Viesis, 7 (February 17, 1910): 149-152.

36 “Prof. Dr. chem. Vilhelms Ostvalds", Jaunā Diena, 7. aprīlis, 1932, 4.

37 "Nobel̦a komitejas jaunākais pārskats [The latest review of the Nobel's Committee]," Burtnieks, no. 5 (January, 1928): 457.

38 "Dinamita karal̦a Nobela traǵēdija [Nobel Tragedy of the Dynamite King]," Pēdèja Brīdī, December 1, 1929, 5.

39 "Kas piespriež Nobela godalgas [Who orders the Nobel Prize]," Latvis, November 25, $1927,7$.

40 "Kultūras ēnas [Shadows of culture]," Latvijas Kareivis, February 2, 1929, 2.

41 “Zum 100. Geburtstag Alfred Nobels,” Rigasche Rundschau, October 14, 1933, 14. 
The most representative interwar medical journal of Latvia - "Latvijas Ārstu Žurnāls [Journal of Doctors of Latvia] - was published from 1923 to 1944. One can find no reviews about the Nobel Prize laureates in physiology or medicine; however, several scientific articles have been devoted to the Nobel Prize laureates. Yet again, some Nobel Prize laureates are mentioned in the articles that are devoted to different medical problems which their research dealt with. For example, two articles by Assistant Professor Aleksandrs Bieziņš about rachitis ${ }^{42}$ mentioned the 1929 laureate G. Hopkins "for his discovery of the growth-stimulating vitamins", and Dr. Ernsts Paukulis's article about blastomas ${ }^{43}$ mentioned the 1926 prize winner J. Fibiger as the discoverer of "Spiroptera carcinoma".

During the Second World War, the number of articles that addressed the Nobel Prize decreased, as there were years during and after the war when the prize was not awarded at all - in 1941 and 1942 (see Table).

Award of the Nobel Prizes from 1939 to 1945

\begin{tabular}{lccccccc}
\hline & 1939 & 1940 & 1941 & 1942 & 1943 & 1944 & 1945 \\
\hline Physics & + & + & - & - & + & + & + \\
\hline Chemistry & + & + & - & - & + & + & + \\
\hline $\begin{array}{l}\text { Physiology and } \\
\text { medicine }\end{array}$ & + & + & - & - & + & + & + \\
\hline Literature & + & + & - & - & - & + & + \\
\hline Peace Prize & - & - & - & - & - & + & + \\
\hline
\end{tabular}

The few articles during the Second World War predominantly dealt with Alfred Nobel's achievements in studying nitroglycerin and the application of the explosive properties of dynamites, for example, the three-part treatise. ${ }^{44}$

42 Aleksandrs Biezin̦š, "Rachīts - organisma augšanas vājuma parādība [Rachitis a phenomenon of growth of the body]," Latvijas Ärstu Žurnāls, no. 10 (October 1932): 586-594; Aleksandrs Bieziṇš, "Atbalsta un kustības orgānu augšanas vājums [Support and movement organ weakness]," Latvijas Ärstu Žurnāls, no. 12 (December 1933): 843-851.

43 Ernests Paukulis, "Jautājumi, kas saistīti ar blastomu rašanās būtības izpratni [Questions related to understanding the nature of blastomas]," Latvijas Arstu Žurnāls, no. 9 (September 1936): 357-379.

44 Ed. Kurzemnieks, "Cilvēks, kas atrada nāvi [A person who found death]," Magazina, no. 401 (January 19, 1940): 18-32. 
The publications of "Deutsche Zeitung im Ostland" on their turn, reveal that, from 1942 to 1944, the current Aristide Briand street - next to the oldest and still existing hospital in Riga (founded in 1803) - was renamed after Wilhelm Ostwald (Wilhelm Ostvald Straße).

At the end of the war and during the first years after it, the focus shifted towards describing the Nobel Peace Prize awards after a 5-year break. ${ }^{45}$ However, it should be noted that the Peace Prize to the International Red Cross movement (in 1917, 1944 and 1963) and its representatives (1901) was given a modest coverage by the local press as compared to other nominations.

1946 was the $50^{\text {th }}$ anniversary of Alfred Nobel's death. After the recently experienced horror of war, it stimulated journalists to cover both Nobel's life and legacy. ${ }^{46}$ In the post-war years, the Nobel Prize remained a topic covered by journalists both in the official Soviet Latvian and Latvian exile publications. ${ }^{47}$ Furthermore, in both cases the articles were written in an "ideologically correct" style. The tendency to cover the Nobel Prize awards within an ideological context increased during the 1950s. Bright examples of this are the summaries of Soviet people's protests in Latvian SSR press against awarding the 1958 Nobel Prize in literature to B. Pasternak for his novel "Dr. Zhivago" due to those time Soviet's leader Nikita Khrushchev statement about the novel as anti-soviet and cosmopolitic. ${ }^{48}$ The juxtaposition of the political and economic systems of socialism and capitalism was intensifying globally. Cold war ideology was also evident in the Latvian exile publications. In October 1979, a rather lengthy article "Nobel Prize laureates in medicine" by Jānis Āboliņš was published in the newsletter of the Latvian Medical and Dental Association. ${ }^{49}$

45 “Ārlietas [Foreign Affairs]," Bavārijas Latviešu Vēstnesis, November 24, 1945, 8. 46 “Alfreds Nobelis,” Biḷetens: Latvijas Jaunatnes Kristīgā Savienība, no. 4 (November 1, 1946): 1 .

47 "Kā izsniedz diplomus nemirstībai [How to issue diplomas for immortality]," Laiks, December 17, 1949, 6.

48 “VĻKJS Centrālās komitejas svin̄̄gs plēnums [VIKKS Central Committee’s solemn plenary session]," Padomju Jaunatne, October 30, 1958: 1; "Latvijas rakstnieki nosoda renegātu [Latvian writers condemn the renegade]," Literatūra un Māksla, November 1, 1958, 4.

49 Jānis Āboliṇš, "Nobel̦a prēmijas laureāti medicīnā [Nobel Prize Winners in Medicine]," Latviešu Ārstu un Zobārstu Apvienības Apkārtraksts, no. 117 (October, 1979): 29-30. 
The article was biased and ideologised. For example, only Paul Ehrlich was mentioned as the 1908 Nobel Prize laureate in physiology and medicine, omitting the second laureate Ilya Mechnikov.

Among the questions of particular importance for the Latvian press regarding the Nobel Prize was "Why didn't Rainis receive the Nobel Prize?". O. Ģerts even used this topic in the title of his article published in the Latvian Communist Party newspaper "Cīña". 50 The famous Latvian writer Rainis (1865-1929) had been erroneously mentioned as a nominee and a potential laureate of the Nobel Prize in literature for years. The declassified Nobel Foundation archival records show that Rainis was never nominated for the Nobel Prize, contrary to another Latvian writer Edvarts Virza (1883-1940) who had been nominated four times. ${ }^{51}$

At the end of the third period (1945-1991) of the Nobel Prize coverage in the press, in 1985 the Nobel Peace Prize was awarded to "International Physicians for the Prevention of Nuclear War" (IPPNW). The Latvian SSR counterpropaganda newsletter "Dzimtenes Balss" published a letter by a physician from Dobele, Karina Ozolina ${ }^{52}$ : "Me and my husband are both physicians. All these years, we have been following eagerly the movement 'World Physicians for the Prevention of Nuclear War', which has also been named 'The Event of the Year'. This year, this movement has been awarded with the Nobel Peace Prize that proves that physician movement has an important role in the common fight for peace." 53

Pauls Stradins Museum for History of Medicine was a collective member of the Latvian SSR IPPNW National Committee. The activities of the movement "International Physicians for the Prevention of Nuclear War" were represented in the regular exposition and exhibitions of the museum for a long time. The Museum participated in different events of the movement, for example, signed an appeal to the leaders of the world

50 O. Gerts, "Kāpēc Rainis nesan̦ēma Nobel̦a prēmiju [Why Rainis did not receive the Nobel Prize]?" Cinna, February 19, 1965, 4.

51 “Nomination Database," Nobelprize.org. Nobel Media AB 2014, accessed on June 25, 2018, http://www.nobelprize.org/nomination/archive/show_people. php?id=9669.

52 The name of Karina Ozolina has not been found on the list of Latvian medical practitioners.

53 “Gada notikumi '85 [Events of the Year '85]," Dzimtenes Balss, January 4, 1986, 4. 
superpowers. ${ }^{54}$ With its special exhibitions dedicated to the history of the movement, the museum participated in several international congresses of IPPNW: in Moscow (1987), in Hiroshima (1989)55, in Stockholm (1991), and in Mexico City (1993). Documents and physical evidences of the IPPNW movement are stored in the collection of the museum.

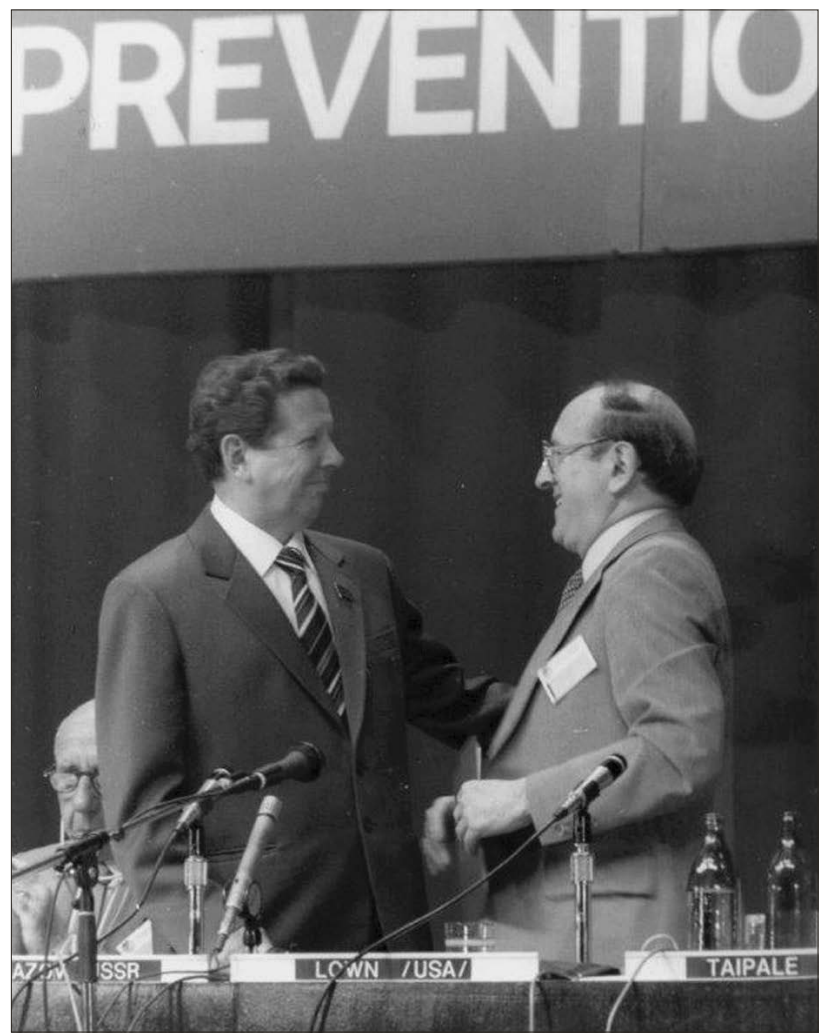

Bernhard Lown (on the right) and Evgeny Chazov (on the left) - co-founder of the "International Physicians for the Prevention of Nuclear War". Moscow, June 1985

(Photographer: unknown. MVMp 10796 Ffp 2528)

54 "Tava vēstule lielvalsts vadītājam [Your letter to the head of a great power]," Padomju Jaunatne, January 7, 1989: 4; Juris Salaks, "Lai viesi neviltos [Not to let the guest down]," Padomju Jaunatne, November 3, 1988, 2.

55 Oskars Martinsons, "Ne Nevadā, ne Semipalatinskā [Neither Nevada nor Semipalatinsk]," Cinna, November 1, 1989, 4. 


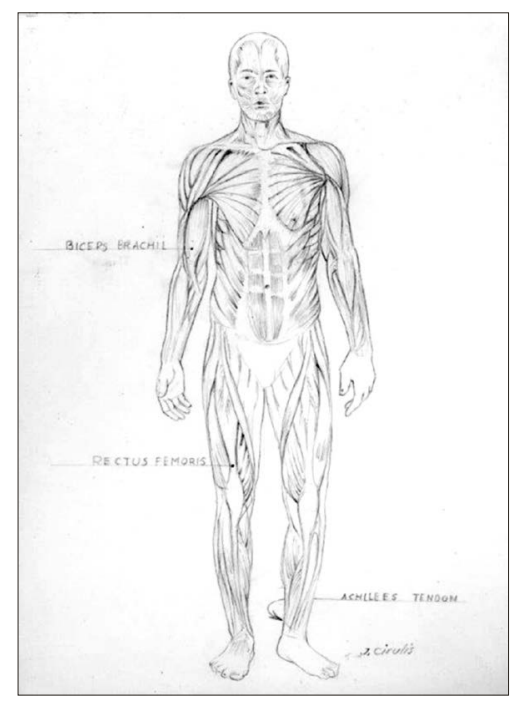

Jānis Cīrulis. Anatomical drawing. Around the 1960s (MVM 57245 Tdaž 1354)

After Latvia regained its independence, initially the number of publications about the Nobel Prize and its laureates substantially increased. The largest newspapers specifically mentioned that the information was provided by their special reporters in Stockholm. ${ }^{56}$ However, in the subsequent years the number of publications on the topic decreased. Although the majority of the articles were predominantly informative, more comprehensive analytical reviews were also published, ${ }^{57}$ mostly translations of foreign publications. The magazine "Latvijas Ārsts" published summaries on the Nobel Prize laureates in physiology and medicine of the respective year, briefly sketching the studies leading to the award. Nevertheless, particular attention was devoted even to indirect connection of Latvia or Latvians with the Nobel Prize. An example of this is a Latvian exile artist Jānis Cīrulis who was the author of the illustrations of surgery books by 1990 Nobel Prize winner Joseph E. Murray. ${ }^{58}$

56 Dace Embrekte, "Nobela prēmijas piešķirtas [Nobel Prizes awarded]”, Diena, December 14, 1991, 8.

57 "Nobela laureātu arhīvi - Nobela institūtā [Archives of Nobel Laureates - at the Nobel Institute]," Diena, April 15, 1993, 11.

58 O. Akmentiņš, "Latviešu mākslinieku devums medicīnā [The contribution of Latvian artists to medicine]," Laiks, January 2, 1991, 3. 
In 1991, the U.S. Helsinki Commission nominated people from all three Baltic countries for the Nobel Peace Prize for nonviolent struggle for independence as an instrument of international pressure to help Baltics regain freedom. ${ }^{59}$ However, this topic did not gain wide coverage in the local press.

\section{Laureates visiting Latvia}

Several Nobel Prize laureates have visited Latvia which also was brought up in the press. In 2008, Harald zur Hausen received the Nobel Prize in physiology or medicine for the discovery of human papilloma viruses that cause cervical cancer. In 2011 he visited Latvia and Pauls Stradins Museum for Medical History, leaving a record in the guest book. He also revealed his connection to Latvia in a press conference, noting that "at least $50 \%$ of my genes are Latvian. Also, my mother told me a lot about Riga in my childhood." ${ }^{\circ}$ Harald zur Hausen's mother was born and raised in Riga. In honour of his parents, Professor zur Hausen founded "The Melanie and Eduard zur Hausen Foundation" to support graduate students from the Baltic countries seeking to complete their $\mathrm{PhD}$ in the German Cancer Research Centre. ${ }^{61}$

In 2011, for the first time since 1960s, Herta Müller, the 2009 Nobel laureate in literature, visited Latvia. ${ }^{62}$ In 2011, a laureate of the same year in literature Tomas Tranströmer visited Riga for an opening ceremony of his book published by the publishing house "Mansards". He was recently announced the laureate but received his prize after the visit to Latvia. ${ }^{63}$

59 "People of the Baltics nominated for 1991 Nobel Peace Prize," Awakening, June 30, 1991, 2.

60 "Nobela prēmijas laureāts aicina Latvijas jaunos mediķus pieteikties stipendijām [Nobel Prize winner invites young medical practitioners to apply for scholarships]," Diena, September 7, 2012, https://www.diena.lv/raksts/latvija/zinas/nobelapremijas-laureats-aicina-latvijas-jaunos-medikus-pieteikties-stipendijam-13966715

61 “Melanie and Eduard zur Hausen Fellowship," Deutsches Krebsforschungszentrum, accessed June 27, 2018, https://www.dkfz.de/en/phd-program/Fellowships.html

62 "Hertas Milleres - Nobela prēmijas laureātes un romāna "Elpas šūpoles" autores vizìte Latvijā radījusi plašu sabiedrības interesi [Hertz Miller's - Nobel Prize Laureate and author of the novel "Swing of Breath" - visit to Latvia has given rise to a wide public interest]," Zvaigzne ABC, April 18, 2011, accessed on June 27, 2018, http://www.zvaigzne.lv/lv/jaunumi/aktualitates/60581-hertas_milleres_-_nobela premijas_laureates_un_romana_elpas_supoles_autores_-_vizite_latvija_radijusi_ plasu_sabiedribas_interesi.html.

63 “Ar sprādzienam līdzīgu iznācienu [Blast-like runoff]," Latvija Amerikā, November $12,2011,3$. 


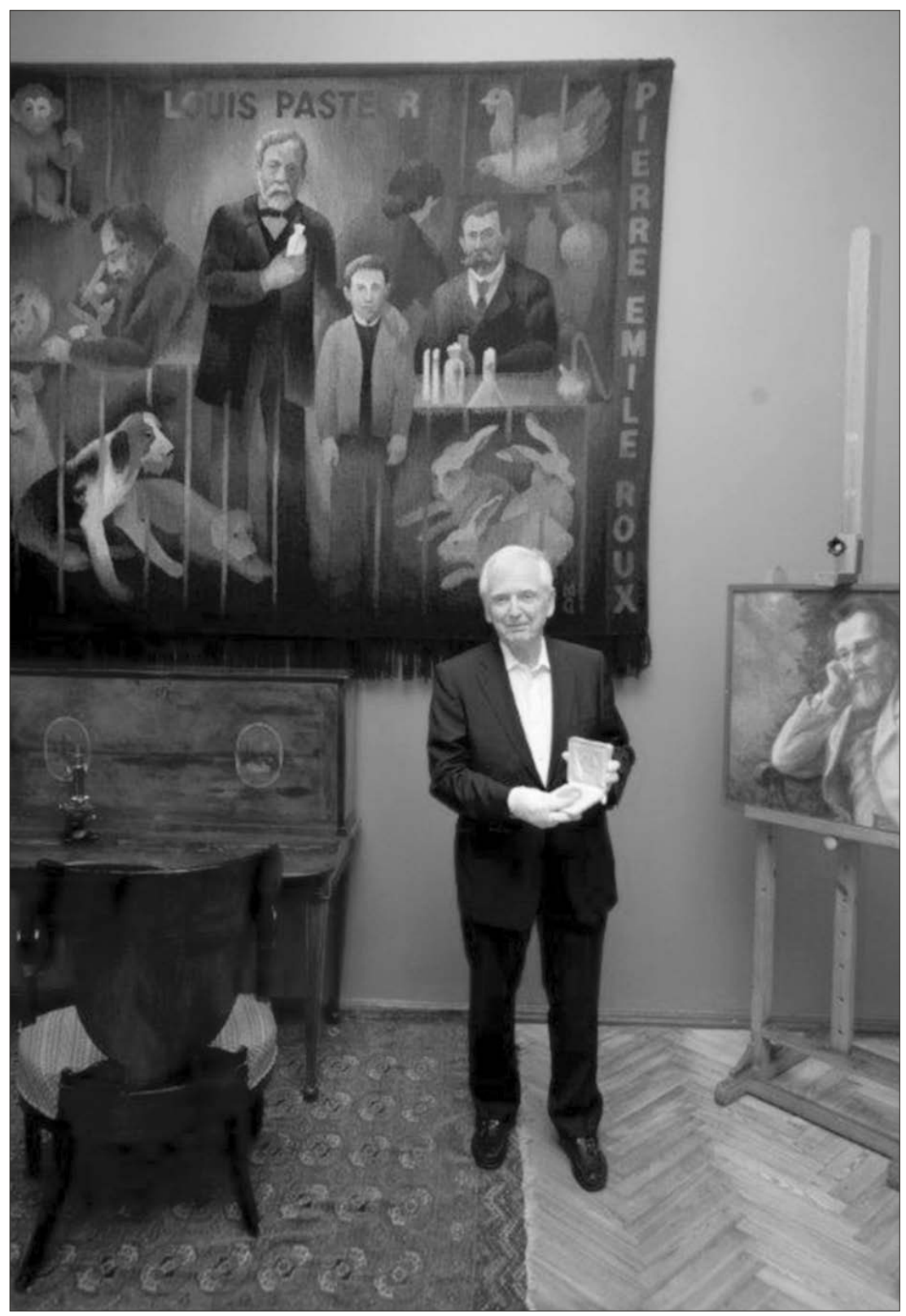

Professor Harald zur Hausen in Pauls Stradins Museum of the History of Medicine. September 2012, Riga (Photographer: Didzis Kadaks) 


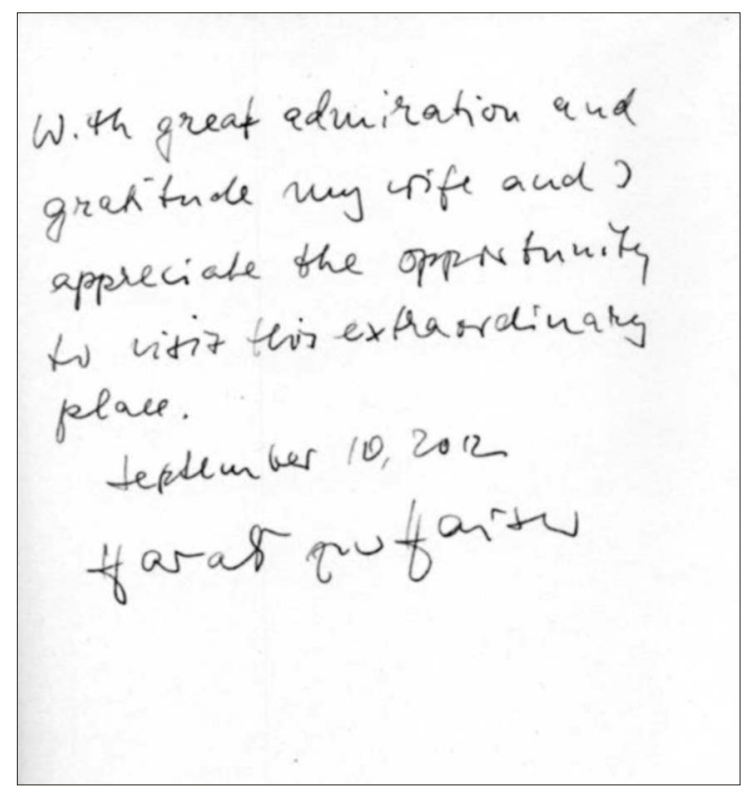

Professor Harald zur Hausen's entry in the guest book of the museum. September 2012, Riga (Photographer: Didzis Kadaks)

On December 8, 2011, during a memorial event dedicated to Alfred Nobel, the Swedish Ambassador to Latvia Mats Staffansson presented the Nobel dinner set in the Art Museum Riga Bourse. It was designed by Swedish designers for the festive dinner dedicated to the $90^{\text {th }}$ anniversary of awarding the Nobel Prize in 1991 (still part of the regular collection of the museum). ${ }^{64}$ The dishes dedicated to this festive event could be purchased in Riga during the 1990s.

${ }^{64}$ Ingrīda Drazdovska, "Muzejam dāvās traukus no Nobela pusdienu servīzes [The museum is presented with dishes from the Nobel lunch service]," Dienas Bizness, December 7, 2011, http://www.db.lv/zinas/muzejam-davas-traukus-no-nobelapusdienu-servizes-249224. 


\section{The Only Nobel Prize Medal in Latvia}

The only Nobel Prize medal in the Baltic States is exhibited at Pauls Stradins Museum for History of Medicine in Riga. ${ }^{65}$ Given his close connection to Riga, one might think that it is Wilhelm Ostwald's medal, but it is not. Paul Stradins Museum for History of Medicine keeps the Nobel Prize medal in physiology or medicine that was awarded to Ilya Mechnikov $(1845-1916)^{66}$ in 1908 (Mechnikov's Nobel Prize diploma is kept in the Pasteur Institute in Paris).

How did Mechnikov's Nobel Prize medal and other of his rewards and personal items end up in a museum in Riga? Mechnikov has never visited Riga and his only connection with the city is that Riga Russian Medical Association ${ }^{67}$ accepted him as an honorary member after he had received the Nobel Prize. ${ }^{68}$ In her monograph published in 2016, L. Vikhanski

65 Madara Rudzīte, "Medicīnas muzejā apskatāma Latvijā vienīgā Nobela medaļa [The only Nobel Prize in Latvia exhibited in the Museum of Medicine]," Latvijas Sabiedriskais Medijs, January 10, 2014, https:/www.lsm.lv/raksts/dzive--stils/ izklaide/medicinas-muzeja-apskatama-latvija-vieniga-nobela-medala.a74544/.

66 The medal of the Nobel Prize in physiology or medicine has been designed by a Swedish sculptor and engraver Erik Lindberg (1875-1966) in 1902. The description of the medal: a two-sided medal, $66 \mathrm{~mm}$ in diameter, made of 23 carat gold, total weight: 204,6 grams. The front side of the medal depicts Alfred Nobel's portrait from a side-view and has an inscription "ALFR. / NOBEL" on the left side and the years of his life on the right side: "NAT. / MDCCCXXXIII / OB. / MDCCCXCVI". There is also an inscription "E. LINDBERG 1902" in a smaller case on the bottom left side along the edge. The obverse depicts a woman that symbolises a medical genius who holds an open book on her lap and collects water pouring from a cliff stream in a vessel to quench a sick girl's thirst. There is a Latin phrase on the upper half along the edge: "INVENTAS VITAM IUVAT EXCOLUISSE PER ARTES" ("And they who bettered life on earth by their newly found mastery"), which is a paraphrased quote from Virgil's "Aeneid" book 6, verse 663. There is an inscription in Latin on the left side along the edge "REG. UNIVERSITAS" that continues on the right side "MED.-CHIR. CAROL." (Karolinska Institute of Medicine and Surgery). There is another medical symbol on the bottom right side a snake wrapped around a vessel and an inscription in a smaller case "E. LINDBERG". The laureate's name "E. METCHNIKOFF" is engraved in a specially marked area on the bottom of the medal ("E" is the initial of his name transcribed to French - Elias), as well as the year in Roman numerals when the prize was awarded to him: MCMVIII.

67 Founded in 1888 with a purpose for scientific communication between physicians. Members of the society needed to graduate the medical faculty in University in the Russian Empire. The society owned the hospital on Elizabetes Street 20 in Riga.

68 "SocietyofRussianDoctorsinRiga. Notification of electiontothehonorarymembers. March 22, 1908," Archive of the Russian Academy of Sciences, fund 584, opis' 2, file 69b, list 1. 
mentions another connection between Mechnikov and Latvia. According to her, some women from Riga might be legal heirs of Mechnikov's memorial objects and that they have been seized and kept in four private safes in the Credit Lyonnais bank in Paris up to today. ${ }^{6}$

The history of the collection of Mechnikov's memorial objects and awards has been possessed by several institutions. After Mechnikov's death in 1916, his second wife, Olga Mechnikova, tried to preserve her husband's scientific heritage. Initially she offered the materials to the Pasteur Institute in Paris, but the collection went to Moscow and was kept there in different institutions until 1975, when the Presidium of the Medical academy of the USSR voted to transfer the collection, except for manuscripts and documents, to Pauls Stradins Museum of the History of Medicine in Riga so as to preserve the collection and ensure its accessibility. The received collection included Mechnikov's books, scholarly papers, paintings, Mechnikov's orders and medals, including the Nobel medal. ${ }^{70}$

Ilya Mechnikov's own attitude towards his Nobel Prize was ambivalent. One can assume that he had expected to receive it. Foreign and Russian scientists had nominated him 70 times (see Table).

Nomination of Ilya Mechnikov for Nobel Prize by scientists from the Russian Empire and abroad

\begin{tabular}{lcccccccccc}
\hline & $\mathbf{1 9 0 1}$ & $\mathbf{1 9 0 2}$ & $\mathbf{1 9 0 3}$ & $\mathbf{1 9 0 4}$ & $\mathbf{1 9 0 5}$ & $\mathbf{1 9 0 6}$ & $\mathbf{1 9 0 7}$ & $\mathbf{1 9 0 8}$ & $\mathbf{1 9 0 9}$ & Total \\
\hline Foreign & 3 & 2 & 3 & 18 & 7 & 7 & 7 & 10 & 4 & 61 \\
\hline Russian & & & & 1 & 1 & & 4 & 3 & & 9 \\
\hline
\end{tabular}

His spouse O. Mechnikova in her biographical book about her husband writes that he, with his wit characteristic and slight irony, said that "the Nobel Prize, like a magical wand, revealed the importance of his study to general public". ${ }^{71}$ However, due to various reasons, the relevance of this award as compared to numerous other orders, medals and recognitions that he had received seems to have been relatively low to him.

69 Luba Vikhanski, Immunity: How Elie Metchnikoff Changed the Course of Modern Medicine (Chicago: Chicago Review Press, 2016), 266.

70 Juris Salaks, The Ilya Mechnikov Collection in Riga, in History of Allergy, Chemical Immunology and Allergy 100, ed. K.-C. Bergmann and J. Ring (Basel: Karger, 2014), 405-408, https://doi.org/10.1159/000360343.

71 Olga Mechnikova, Zhizn Ili Ilicha Mechnikova (Moskva, Leningrad: Gosudarstvennoe, 1926), 160. 


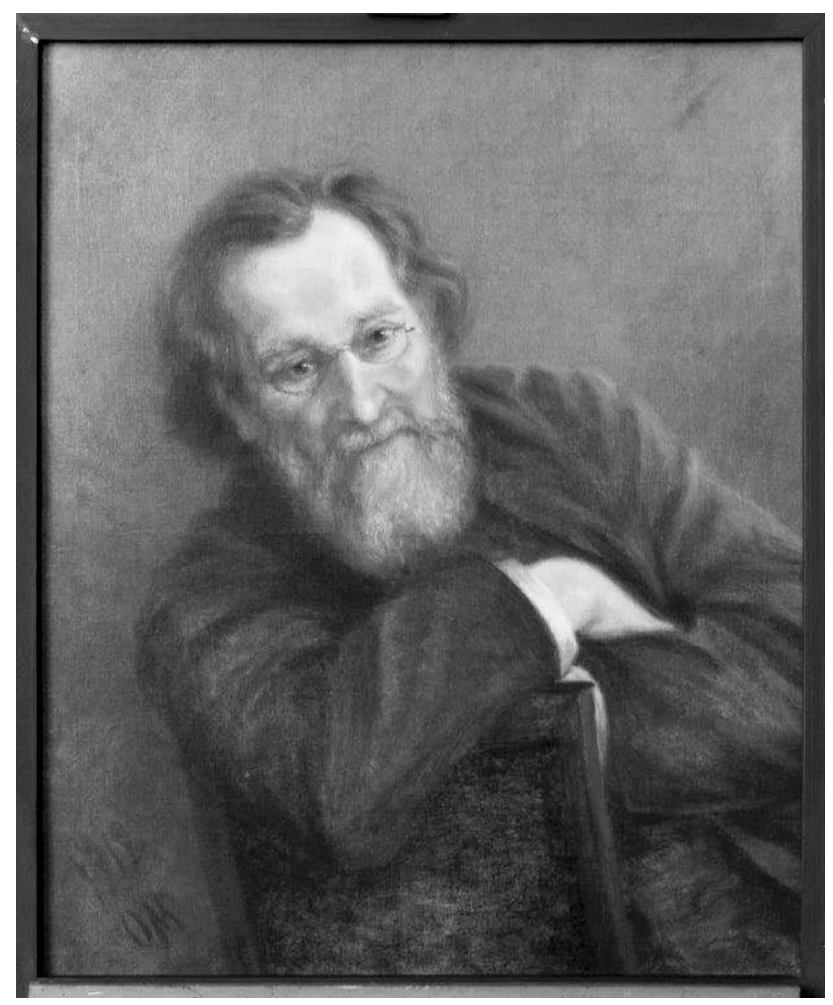

Portrait of Ilya Mechnikov. Artist: Olga Mechnikova, 1912.

Canvas, oil (Photographer: Janis Pavlovskis. MVM_6491_A)

With a formal excuse of having a pre-planned lecture course in the Pasteur Institute in Paris, he did not attend the award ceremony in Stockholm on December 10, 1908. In December 1908, in his letter to his first Pasteur Institute student N. Chistovich he wrote: "I maintain that the International Medical Congress award that I received in 1903 is incomparably more prestigious than the Nobel Prize, because it is awarded by an international committee. But it is worth only 5000 franks and, thus, does not catch a lot of attention. Whereas, the Nobel Prize, naturally, is more pleasant financially." 72

72 Ilya Mechnikov's letter to P. Chistovich, June 19, 1908, mvm 19.643, R.22.845, Pauls Stradins Museum for History of Medicine, Collection of Handwritings and Documents. 

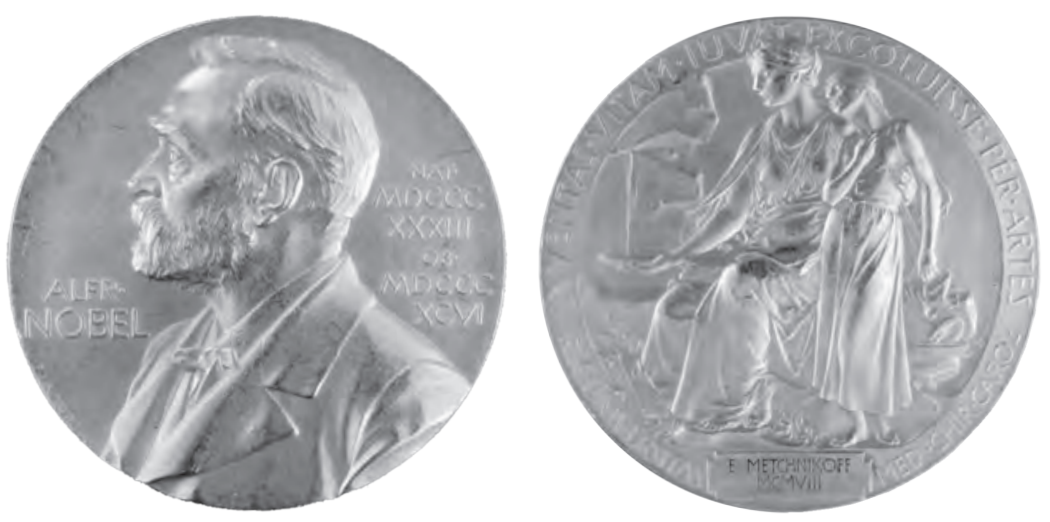

Ilya Mechnikov Nobel Prize gold medal: avers and revers (Photographer: Leons Balodis. MVMp_21621_Fdp_439_10_4; MVMp_21621_Fdp_439_10_4)

Even five years after he received the Nobel Prize, I. Mechnikov compared different medical award committees undoubtedly not in favour of the Nobel Prize Committee: "I pay attention to these international congress awards. Although their financial worth is immeasurably smaller than that of the Nobel Prize, their moral importance is much greater, because they have been awarded by incomparably more competent committees." 73

It's unlikely that the reason of the resentment is the relatively long period it took for Mechnikov's success to be recognised, if one could consider the beginning of that period 1883, when his article "Untersuchungen über Verdauung bei wirbellosen Thieren die intracelluläre"74 (Studies about the intracellular digestion of the intervertebrates) was published in Vienna, mentioning the hypothesis of phagocytosis for the first time.

73 I. I. Mechnikov, Paterovskii institut v Parizhe (Po povodu ego 25-letiia), 5 (18) sentiabria, 1913. In Stranitsy vospominanii. Sbornik avtobiograficheskikh statei (Moskva: AN SSSR, 1946), 111. (Original article was published by the newspaper "Russkoe Slovo," November 1, 1913.)

74 "Untersuchungen über die intracelluläre Verdauung bei wirbellosen Thieren," in Arbeiten aus dem Zoologischen Institut der Universität Wien und der Zoologischen Station in Triest (Universität Wien, 1883), 5; 141-168. 


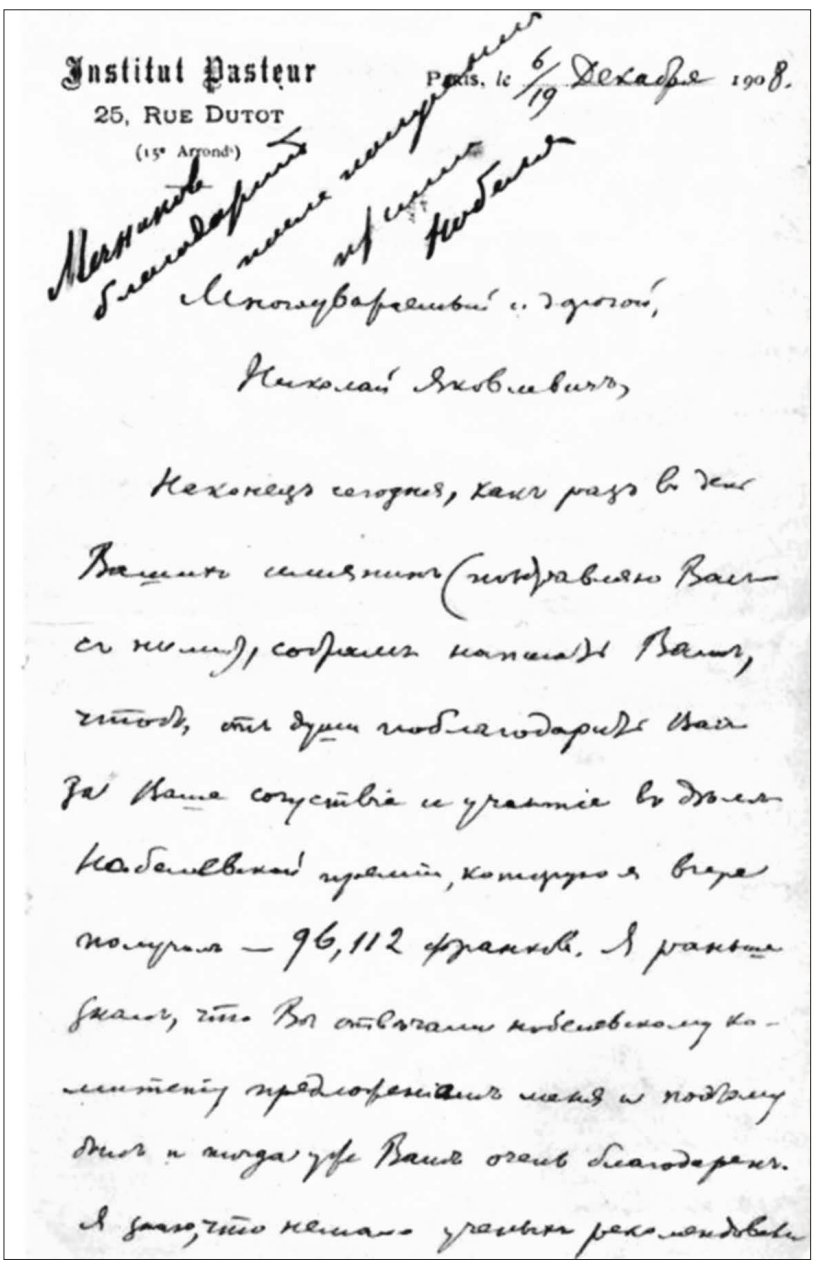

First page of the letter from Ilya Mechnikov to Nicolai Chistovich. Paris, December 6/19, 1908 (R 22845)

Ilya Mechnikov himself considered that Robert Koch's achievements in medicine were greater than those of any other and that he should have been awarded the first Nobel Prize. He himself had nominated R. Koch already in 1901. There was only one more person that I. Mechnikov had nominated several times, namely Emile Roux, his colleague from the Pasteur Institute.

The most important reason for disappointment was definitely the fact that the Nobel Prize was jointly awarded to I. Mechnikov and P. Ehrlich. 
In general, the relationship between both scientists can be considered as a good example of scientific ethics. Although, they were irreconcilable opponents in science (Mechnikov with the cellular (phagocytosis) theory and Ehrlich with the humoral immunity theory), they treated each other with respect in real life. Their scientific debates even stepped out of academic circles and, for example, served as a basis for Bernard Shaw's play "Doctor's Dilemma" (1906).

Already in 1905, a microbiologist A. Calmet offered the Nobel Prize Committee a compromise, by splitting the Prize between I. Mechnikov and P. Ehrlich ${ }^{75}$. In 1908, the Committee diplomatically took the opportunity. The decision of the Committee was not a confirmation of their theories, the prize was awarded in recognition of their great achievements in the development of immunology.

The innate immunity theory (represented by Mechnikov) and the acquired (adaptive) immunity theory (represented by Ehrlich) was confirmed only in 2011, when the Nobel Prize was awarded jointly to three scientists - Bruce A. Beutler, Jules A. Hoffmann and Ralph M. Steinman for the discovery of the innate immunity activation mechanism, the dendritic cells and their role in the activation of the adaptive immunity.

\section{Conclusion}

The interest of the public and the press to the Nobel Prize in the territory of present-day Latvia can be traced since the will of Alfred Nobel was announced. There are no ethnic Latvians among the Nobel Prize laureates. The most famous Nobel Prize laureate in Latvia is Wilhelm Ostwald, a Baltic German who was born in Riga in 1853, graduated and then worked at the University of Dorpat from 1875 to 1881 and after that was a professor at Riga Polytechnicum, from 1881 to 1887 . He was awarded the Nobel Prize in chemistry in 1909. Certain Nobel Prize laureates of the second half of the $20^{\text {th }}$ and early $21^{\text {st }}$ centuries have indirect ties with Latvia, Estonia and Lithuania.

Riga honours its Nobel Prize laureates and nominees. Monuments have been erected in their (Ostwald, Valden, Bergmann) honour. The famous Latvian artist Janis Strupulis has created an award and commemorative

75 Axel Cäsar Hüntelmann, "Paul Ehrlich und der Nobelpreis. Die Konstruktion wissenschaftlicher Exzellenz,” Berichte zur Wissenschaftsgeschichte, 41, no. 1 (2018): 47-72. 
medals (Ostwald, Valden, Bergmann). There is a street named after Ernst von Bergmann and a school named after Wilhelm Ostwald in Riga.

A special role in promoting the laureates and nominees of the Nobel Prize belongs to Pauls Stradins Museum of the History of Medicine in Riga. Documents, prints and photographs are kept in the museum's storage, exhibits are displayed at the permanent and temporary exhibitions. A sculpture of Ernst von Bergmann is installed in the courtyard of the museum. In the museum there is a world famous memorial collection of the Ilya Mechnikov - a Nobel Prize winner in physiology and medicine in 1908. The collection contains over 400 items, including his Nobel Medal.

\section{Nobela prēmijas atgādinājumi Rīgā: mediju atbalss un liecības}

Rakstā analizēts Nobela prēmijas pētījumu turpinājums Latvijas diskursā. Prēmijas saistībai ar Rīgu, galvenokārt tikai ķīmiķa Vilhelma Ostvalda sakarā, iepriekš pievērsušies zinātnes vēsturnieki Jānis Stradiňš un Alīda Zigmunde. Raksta pirmā daļa veltīta Nobela prēmijas saistībai ar Latviju un tās augstskolām, analizēts Nobela prēmijas piešķiršanas atspogulojums vietējos un trimdas plašsaziņas līdzeklısos dažādos 20. gs. Latvijas vēstures posmos, izsekota Latvijas saistība ar nepubliskotajām Nobela prēmijas nominācijām Nobela komitejas arhīvā Stokholmā. Otrajā dạ̦ā apskatīta Nobela prēmijas fizioloǵijā un medicīnā 1908. gada laureāta Iḷjas Mečņikova kolekcija Paula Stradiņa Medicīnas vēstures muzejā, publicēts detalizēts Iḷjam Mečnikovam piešķirtās Nobela medaḷas apraksts un viņa neviennozīmīgās pārdomas par šo balvu. Raksts ir daļa no izpētes projekta "Nobel̦a savienojumi Baltijas reǵionā".

\footnotetext{
Juris Salaks

Dr. med., Rīgas Stradiṇa universitātes Medicīnas vēstures institūts, profesors / Institute of the History of Medicine at Rīga Stradiňš University, Professor

Nils Hansson

$P h D$, Heinriha Heines Diseldorfas universitāte, asociētais profesors /

Heinrich Heine University of Düsseldorf, Assoc. Professor
} 